\title{
PAT, LEYHAC'SEN : 猫の行動研突
}

Verhaltensstudien an Katzen. Paul Parey, Berlin, 1955.

人間に最も親しまれている動物の中で犬に関しては W.FISCHEL 等の優れた研究があ るのに反し猫の行動研究で体系的なものはこれまで殆どなかつた。人間に近くて遠い猫 に関するLEXHAUSEN の比較行動学の立場からなされたこの研究は墨富な興味ある写真 (76葉) の扫入と相俟つてこの書を專門家だけでなく凡と動物行動の 理解に 関心をもつ 者の恰好な指針たらしめている。

全篇は「蒦物に対する行動」と「社会行動」の二部に大別され，著者が 1949-1955年 の間に Bonn と Göttingen の動物学教室で30匹匹の飼育された猫及び無数の日常場面に 新ける猫の行動研究からから得たデーターがこの動物の生態を浮彫的に構成している。 特飞他の猫類, Rotluchs, Karakel, Puma, Gepard, Tigerkatze 等との此較行動研 究は LOLENz, TINBERGEN, SeITz 等が近時体系化しつつある比較行動学の線沃添うも のであつて，これまでなされた唃乳類以外の精細な研究と充分比肩しうる内容をもつも のと言えよう。

第一部で注獲物への接近, 捕方方, 殺し方, 喰べ方等が精緻な観察に基いて述べられ ている。第二部は領分 (Revier) 行動, 猫同志の出会い, 雄猫同志の争い, 兄弟間の順 位, 人間飞対する行動, 性行動等の記載にあてられている。

次飞第一部の中から一二與味ある事実を述べてみると：

\section{(I) Beuteschema の確定}

凡そ生活体の場面行動の理解は当該行動を解発する刺战（解発体とも言はれる）の確 定的操作をはなれてはあり得ない。ここに解発体と言うのは生活体が知覚する外的情洗

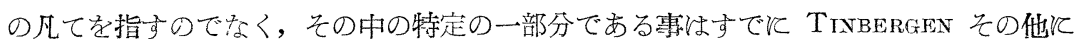
よつて実験的㳉汒されている。ある生得的反応が一定の解発体に侾存するのは凡ての 生活体が一定の反応を解発せしめる神経感覚機構を具兄ているからであり，これる生得 的解発機檴 (AAM と畍称する) とよぶ。

猫の AAM の分析K当つて LExhAUSEN は四種の解発体を区別する。(1) 捕蒦行動

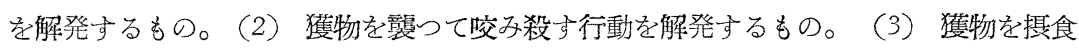
する行動を解発するもの。（4）摂食開姢の部分を沃定するもの。（1）については, 猫の眼前を斜めて横切るか又は猫より離れて行く余り大きすぎない対象は凡て追跡一捕 獲行動の解発体となる。

ただし，この場合解発体は緩慢に動くだけでは不充分で，一定の空間距離をある速度 で動き去る事が大切な条件となる。猫に正面から向つて来る対象は猫を警かせ 尻込みさ せるだけで（1）の解発体とはならない。(2)と（4）飞関しては興味ある実験の結果(頭 
部を尾部に縫いつけたラッテや頭部を切断したラッテ等を用いる）次の二点が結論され た。

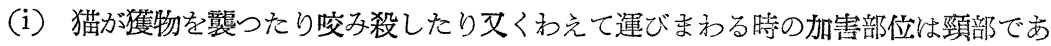
るが，これは対象の頭一胴体分節の視的把握依存する。従つて対象が頭部を欠いてい る時は任意の部位で捕捉する。（ii）掇食を開始する部位は視的統裁によらず触覚汇よ るものと思はれる。従つて頭部から開始されるとは限らない。

（3）飞関しては味覚, 嗅覚が役割を果している代らうと推測される以上確定的な解 発体を明にする事は目下のところ出来ない。

（2）飞関係して興味深い事は猫が獲物の毛や犲根をむしる行動のリズム，即ち獲物を くわえて振りまわす行動とむしる行動との交替時間が他の猫類との此較に䅂いて考察さ れている点である。Rupfung と Abschlenderung との出現頻度の此柱 Luchs や Serval では1：1であるの対し, Tigerkatze やPuma では 2：1 となつている。ヌリズ ムの外沉しる強度も両群飞未いて夫々異なり後者は前者よりはるか强烈である。ふ つうの猫とトラ猫によつて夫及むしられた雀の狗根が四辺死散している現場の写真は 幾多の写真の中で特印印深いものがある。上記の事実は一見大きな相違を示している 夫々の動物が系統発生的に夫々の系列们所属寸る位置を察知せしめるという点で重要 である。換言すれば，比較行動学的考察を施さず算なる外観上の類似から系続発生的 な位置ら゙けを行う試みが如何飞伦険であるかをこの一事はょく物語つている。LORENZ， TINBERGEN 等が鴨の転位行動 (Übersprungverhalten) としての「狒みがき」が 鴨の種類によつて一見同じ型に見完実は異なる様式飞䚻属する所以を明らかとした研究 を思いあはせるなら LEYHAUSEN のこの考察は頗る意義深いるのと言はねね゙ならない。

(II) 捕蒦行動の発達

凡そ一切の獲物捕獲行動は純然たる生得的な行動であるが，ただ咬み殺す、行動の最初 の解発契機以獲物自体ではなく母猫加他の兄尊から「附加的」飞与兄られる。母猫が仔 猫の眼前で未だ生きている獲物を一度放して再び捕えるとしてもそれは泆して保猫に， 「して見せる」のでない。従つて仔猫はこれから「そのやり方」を決して学びとるもの ではない。仔猫がこの場合獲物を捕觉るのは急速洮げ去らうとする対象が AAM に

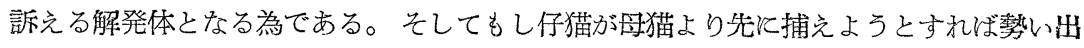
来るだけ早く確実に捕えねばならない。この「競争」がいかゆる「附加的與害」へと駆 り立てる一つの要因となる。勿論単なる前肢による捕捉と鋭い橉による咬む行動との間 そは無数の移行型があるわけであるが，猫が獲物を咬み殺す行動の発達はある発達の時

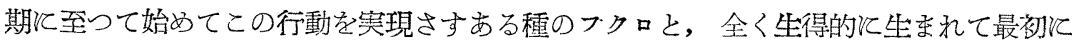
みる獲物を完全な仕方で咬み殺すイタチとの丁度中間の位置を占めるるのと思はれる。

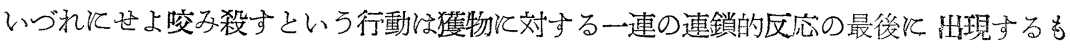
ので，この点で内因性行動の最終涀はれる最終行動（狭翊の本能行動）は個体発生の 
最初《みられる，という KORTLANDT の定則は妥当しないことになる。ここで LEYHAUSEN が到達した次の結論は注目に価する。即ち, 内因性の最終行動はもしそれが発達 のある時期 (H. RÄBER がフクロについて述べている sensible Periode と同じ意动で)

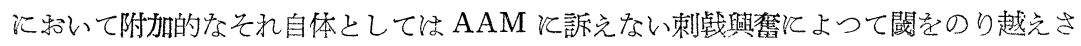
せられない時は後に到つて発現しないかもしくは甚しく発現が括くれる。

この結論が何故注目すべきかと言うと，この見解は猫の「ネズミ殺し」の行動関す るKUo の有名な経験による習得説が実に25年を経た今日始めて正面から批判される事 になるからである。著者の見解からするとこの KUO の研究は幾多の条件上の不備を示 していて何よりもとれは「猫の側からもネズミの側から見ても非生物学的」である。第 一 KUo の用いた実験箱 $(91 \times 61 \times 61 \mathrm{~cm})$ は狭小で，「狭小な生活空間内の侵大者は 猫にとつて無気味な存在」である。著者の一事例によると狭い檻の猫はネズミと牛時間 そわたる「争い」の結果ついに疲れ果てたネズミを殺し所謂 Erleichterungsspiel(Lindemann の「踊りまわり」を示した。KUoの一試行は30分であるから結果に特いて 「ネズミ殺し」が見られたにしてもとれがどの様な行動経過を辿つたものか，遊びの要 素がどの程度滔大していたものか判然としない。第二ね KUO は「ネズミ殺し」の巧み な母親に育てられた仔猫はそれを見習うと言つているが 他の赛験群の母猫については充 分なコントロールを施していない。第三に成熟の問題が考慮されていない。

要するに AAM と解発体との関係分析を行はなかつた KUO の習得説は比較行動学の 立場から大きく修正されね柿ならないしかし，母猫の「殺し」を目撃して育つた猫の 大牛がこの行動を示すに至つた事実は認めざるを得ない。それ故ここで問題となるの梳 単なる目撃 (KUo の穾験で仔猫は母猫の殺したネズミに直接触れる事は出来ない)が何 故に仔猫の行動に影響を及ぼすかと言う事である。

この点の説明は割愛して最後に遊びそついて特に注目すべき点だけを还べることにす ๖。

内因性行動は (Appetenz 行動もらくめ) 数多の部分から構成されている。この部分 行動のあるものが寒現すべき全体行動の方向に向つて解発されている途上で中断し，他 の行動形態へ突然移行する事がある。これが「真の遊び」現象の前提となる。著者の考 想の特色はこの現象を v.HoLsT の見出した中枢神経の「相対的共働」の原理で説明して いる好にある。著者は遊びを gehemmtes Spiel, Stauungsspiel, Erleichterungsspiel の三種に区分しているが，第1の遊びに特いて転位行動が見られるのはこの種の動物に 物いて扮そらく始めて明確な現象型をとらえたものとして特に意味深い。猫類の転位行 動が蒦物を前にして身を橫たえ自分の前肢をなめるという型をとつているのは面白い。 見るからねい猛なPuma が小さな鴨を橫目でとらみながら橫になつて前肢をなめてい る写真は78葉の写真の中でも最も興味あるものの一つであろう。

第二部では冬種の社会的行動が述ベられているが，領分行動については次の事が結論 
されている。

（I）猫同志の出会い Revier 外の猫は多くの場合 Revier の猫に最初から負け ている。この場合優者が相手の「素性」を知ろうとするのに対し劣者はとの Revier の 「土地カン」を獲得しようとつとめる点が特徵である。な祘, Revier の行動牛径の大き さは一概炕言えない。

（II） 社会的順位 元来社会生活を営まない猫には猿等にみられる様な確然とした順 位は存しない。たた四親を同じくする仔猫相互の間には「大将株」と「ビヶ」とが可世 明白にみられる。しかし，これとてもしばしば身分変動を行う。誰が大将株になるかは、 体力や大きさによつて決まるのではない。この点に関しては不明な事が多い。

（III）猫と人間との関係 この項で著者の述べているところは非常汇面白い。交尾期 以外には他の猫と何等交渉をもたず相互に坬独な生き方をしている猫が何故に人間とは 親密な関係を結ぶのであろうか。

これに答える前に先づ猫の生活というものに眼を転じてみる必要がある。坬独な生活 を送つている猫はまさととの故に自己の Revier 防衞に忙殺されるわけで，それと加え て交尾期には雄同志の烈しい争いが，又同一家族成員間の韭合い，拮抗が限りなくつづ くのが猫の日常生活の有り方である。その為に一般に唃乳動物にみられる「子供らしい 衝動行動」は姿を見せるいとまがないのである。これに反して人間は猫のAAMV訴光 る解発物たるには余りに力弱く，こちらが親愛感をもつて揬すれば猫同志の間には決し てみられない「友情」が成立するのである。もしこの考光方が正しいなら猫は実は猫同 志友人を欲しているのだと言うことが出来よう。それは丁度事ごとに他の人間と衡突す る変人にも比す事が出来ようと著者は言つている。どうして友人を持たないのかと訊ね れば彼は答えて言うだろう。「とんでもない，私は友人が欲しいのだが，どうしてまた 人間はこうもいやらしいものばつかりそろつているんだろう」この比俞は軽妙で頗る面 白い。

(IV) 艾むということ

LEYHAUSEN が本書の最後にふれている問題を簡単にみてみよう。猫が獲物を殺す㗪, 仔を運ぶ時, 交尾の時, 遊びの時洪通しているものは相手の頸部を昗むという行動で ある。ところで交尾や仔運びの㭙の咬み方と殺す時の陵み方との相違は咬む部位の定位 の仕方にあるのでなく前者は拮抗的神経支配により抑制されているという点である。勿 論抑制されていると言つても時恔む力が強く相手淁思はぬ深手を与光る事もある。 乙かし, 神経の共働作用はその犃々の事態によつて明異なる。又殺し以外の時, 特江 仔運びの㭙は適当なくわえ方が出来るまで何回となく試行を繰り返えすの反反して獲物 を直接笠う時には一気に頸部に喰いつく。更に仔運びと殺害との相違は身体全体の種学 方がすでに同じでない。前者の時は前肢を後に引いて頭部を前方え突き出すように構え るのに反し後者の場合は前肢で相手を押え込むようにする。このスタンスの相違を鮮代 
示している二葉の写真は素腈しい実感㹸みちている。著者は比較行動研究から仔運びや 交尾㭙の咬む行動がいづれも発生的には殺書を目的とする咬む行動から由来している所 以を明にしているが，この問題関して最も重要な事は殺寒㫢以外の咬か方がいづれも 中枢からの抑制従つているという点であり, これとついては LORENZ の卓越した研 究がこの現象の発生的な展開の深さを示している。例党ば，二匹の犬が争いの最中に一 匹が敗北して，又は敗北を感じた瞬間炕ふと争いを中絕し相手の前に 無抵抗な身をさら すことはしばしばある。ここで注目すべき事はこの場合敗者の犬が 元来最も敵にさらす 事をさけねね゙ならない部位，即ち頸部をことさら相手の前儀し出すような姿勢をとる という事である。

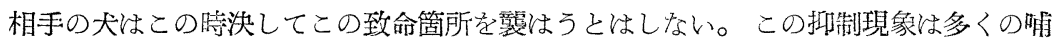
乳動物炕みられるが，い、ば人間の共同生活に和汁るモラルにも対応するこの現象は実 に重要でかつ团難な問題を提起する。攻撃の目標部位がもし無防備な形でさらけ出され るなら睃間にして抑制のAAMの解発体となつて誘意性の符号を一变せしめるのは何故 であるうか。人間に和ける朌利者飞跍坐したり，首を差し出して平伏したり, 脱帽した りする服従行動はそれ自体内因性の反応ではないにしても誘意性の転換化基いている整 は上記の大の場合と同様である。人間とことなり衝動炇支配される動物䎲すし抑制現象 というものが存しないとしたならば凡そ何等かの共同体を形成し 社会的生活を営を事快

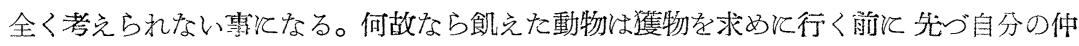

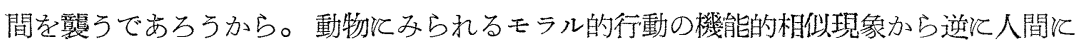
抒いて系統発生的な深い層飞根差寸社会行動の動機づけを比較行動学の考察からさぐり 当てる事は出来ないものか。LEYHAUSEN の焧も行動の考察はこうした関連行いて閣 題を追求してはいないが一見単純とみ兄るこの事実が穾は如何に深い意味をもつものか 知らねね゙ならない。LORENZ の述べているようと現代の世界的危機が結局は人間相互の 保全対するモラルの䚻失《求められるならげこの抑制現象の采統発生的意味を追求す る比較行動学はなた当然 GEHLEN等の目指す人間学へ通路を開くものとなるう。

この LEYHAUsen の書物《は一般の動物心理学が好てで披う智能の問題以は一言もふ れる処がない。しかし動物に「何が出来る」かではなく广との行動は何である」かの解 明を意困する比較行動学の行き方からするなら行動の原型把握が 第一の課題でなければ ならない。

原型把握とはあるがままの行動記述でもなければ，他の動物行動との平面的次元沃

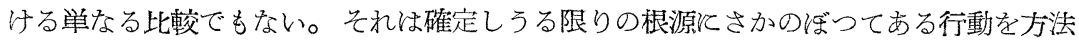
論的批判的自覚のもと洅発堀する事である。

分析と構成の科学的操作注より行動型の系続発生的位置づけと意味づけを確定するこ とでもある。AAM と解発体との関係分析はこの目的の為の一つの重要な操作となる。 しからばこの様な此較行動研究は何を指向するのか。LORENZ 以次の様汇言う。人間 


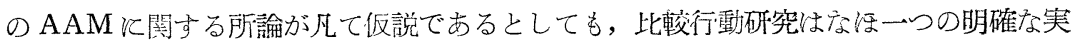
践的な課題をもつている。そして次の一事は少くても仮説でなく真実である。即ち，ある 組織の機能障害を排除する唯一の方法はその組織之障害との因果的分析飞求められる， という一事である。現代の人間を破隇へ追い込えでいる危機が 人間以外の世界飞発する ものでない事以確かである。人類が人類を育しているのだ。武器の発明とそれが使用の 抑制との不一致法破滅を孕九でいる。この破滅と社会的抑䎺との均衡を 再び回復させる 事が凡ての人間の共同責任によく可能であろうか。人類の運命はこの一点にかかつてい ると言えよう。(K.LORENZ : Ganzheit und Teil in der tierischen und menschlichen Gemeinschaft: eine methodologische Erörterung. Studium generale 9, 1950).

LEYHAUSEN の本研究はこうしたペルスペクテイーフから展望した時に始めて正当に 評価されるのではあるまいか。 